\title{
Spatial features of training highly qualified scientific and pedagogical personnel in the South of Russia
}

\author{
Nadezhda Shpak ${ }^{1}$, Yuliya Merinova ${ }^{1}$,Vladimir Latun ${ }^{1, *}$, and Ludmila Nedoseka ${ }^{1}$ \\ ${ }^{1}$ Southern Federal University, Zorge str., 40, Rostov-on-Don, 344000, Russia
}

\begin{abstract}
The key factors of the socio-economic development of society are science, innovation and new educational technologies that shape and reveal the scientific, pedagogical and production potential of the country. The formation of an innovative economic model today is impossible without the intensive development of fundamental and applied research activities, which makes higher educational institutions one of the most influential elements of the implementation of the concept of advanced development of the territory. There is a need to improve the institutional framework, expand the academic network, strengthen interuniversity cooperation for the development and effective operation of the entire educational sphere. The Russian higher education system, which is responsible for the reproduction of professional scientific personnel, is in a state of large-scale transformations, which is reflected in the main institutes for training highly qualified personnel - postgraduate and doctoral studies. Transformations in higher education affect the quality of training of future specialists, and also form a certain imbalance in their territorial organization in different constituent entities of the country. The article discusses the particularity of training, spatial characteristics and provision of subjects of the South of Russia with scientific and pedagogical personnel of the highest qualification.
\end{abstract}

\section{Introduction}

For the development of the modern world, the contribution of science, innovation and new technologies is of great importance. They are among the most important factors in the socio-economic development of any state $[1,2]$. For the successful innovative development of the country, the possibility of technological breakthroughs and advanced scientific developments, the provision of the leading sectors of the economy with a professional personnel reserve, a clearly built and smoothly working system of training highly qualified scientific and pedagogical personnel is needed, whose activities are aimed at forming intellectual capital, developing scientific and technical potential and enrichment of the social and cultural sphere of society.

Over the past decades, postgraduate and doctoral studies in Russia have been in a stage of profound transformations due to the country's joining the Bologna process. The main

\footnotetext{
* Corresponding author: vlatun@yandex.ru
} 
conditions for integration into the Western educational system: the comparability of curricula, the academic flexibility of students and the professional mobility of the teaching staff [3-5] led to the need to modernize the entire higher education [6]. The listed conditions are aimed at revealing the potential of each student, which in the long term should affect all spheres of the economy and society [7, 8]. In connection with the adaptation of education to the generally accepted provisions of the Bologna system, a number of extensive changes followed in the training of highly qualified scientific and pedagogical personnel, which are reflected in the Federal Law of December 29, 2012 No. 273-FL "On education in the Russian Federation" [9]. So, in 2013, there was a separation of postgraduate and doctoral studies, but their direct connection remained unchanged. Postgraduate studies today are part of the education sector - the third stage of higher education, and doctoral studies, in turn, are related and regulated by the scientific sphere of society, which indicates the need to consider the performance indicators of each of the institutions separately, and a more accurate understanding of the ongoing processes [10]. To solve the problem of the growing shortage and uneven distribution of scientific personnel in the constituent entities of the Federation and the successful organization of an integral system of higher education in Russia, it is necessary to be guided by regional indicators of postgraduate and doctoral studies, to take into account the geographical features and socio-economic specifics of each region.

\section{Materials and research methods}

The study of the geographical features of the training of highly qualified scientific and pedagogical personnel in the South of Russia was based on the work of domestic and foreign scientists, geographers, sociologists and teachers dealing with the issues of innovative activity of higher educational institutions of the Russian Federation (Vorontsov A., Vorontsova E., Glebova Y., Yasnitskaya N., Mioara M., Fatkullina F., Morozkina E., Suleimanova A.), the specifics of training scientific and pedagogical personnel in higher education (Ardashkin I., Martyushev N., Sidorenko T., Nilsen S., Pavlenko D., Barykin L., Lemeshev S.), studying the current trends in the development of Russian science and education in the context of globalization (Mingaleva Zh., Mirskikh I., Fedotova O.), analysis of the features of the integration of the Russian pedagogical school into the Bologna process (Mitchel P., Aydarova O., Rezaev A., Kozachek A.).

The main task facing the analysis of the state of the system of training highly qualified personnel is to determine the most favorable and problematic regions in the South of Russia. The study of the degree of provision of the system of training highly qualified personnel was carried out for the constituent entities of the Russian Federation, which are part of the South and North Caucasian Federal Districts. For the regionalization of the subjects of the Southern Federal District and the North Caucasus Federal District, the main characteristics and indicators of the activities of postgraduate and doctoral studies were selected:

1. The number of organizations with postgraduate studies;

2. The ratio of the number of graduate students to the population;

3. The number of graduate students with a thesis defense;

4. The number of research institutes and universities with doctoral studies;

5. The number of graduates of doctoral studies with a thesis defense.

For a qualitative assessment of the degree of development of the system of training young scientists, a point estimation was used. Comparison of actual and numerical indicators through a fixed scale allows us to investigate the availability of personnel for postgraduate and doctoral studies. For system analysis and evaluation, statistical data were taken from the website of the Ministry of Science and Higher Education of the Russian 
Federation, official statistical collections: "Russian Statistical Yearbook" [8], "Regions of Russia. Socio-economic indicators, 2014-2018" [12], "Education in Figures - 2017" [13].

According to the data presented, a distribution was made on a five-point scale, where 1 point is the lowest indicator of the system's provision for training highly qualified personnel, and 5 points, in turn, is the highest indicator. (Table 1).

Table 1. Criteria for scoring the system for training highly qualified personnel in 2018

\begin{tabular}{|c|c|c|c|c|c|}
\hline & $\begin{array}{c}\text { Number of } \\
\text { organizatio } \\
\text { ns with } \\
\text { postgradua } \\
\text { te studies }\end{array}$ & $\begin{array}{c}\text { The ratio of } \\
\text { the number of } \\
\text { graduate } \\
\text { students to the } \\
\text { population }\end{array}$ & $\begin{array}{c}\text { The number of } \\
\text { graduate } \\
\text { students who } \\
\text { defended their } \\
\text { dissertations }\end{array}$ & $\begin{array}{c}\text { Number of } \\
\text { research } \\
\text { institutes and } \\
\text { universities with } \\
\text { doctoral studies }\end{array}$ & $\begin{array}{c}\text { The number of } \\
\text { doctoral } \\
\text { graduates who } \\
\text { defended their } \\
\text { dissertations }\end{array}$ \\
\hline 1 & $1-5$ & 0.1 & $1-20$ & 1 & $1-5$ \\
\hline 2 & $6-10$ & 0.02 & $20-100$ & $2-3$ & $6-10$ \\
\hline 3 & $10-15$ & 0.03 & $110-200$ & $4-5$ & $11-20$ \\
\hline 4 & $16-20$ & 0.04 & $200-300$ & $6-8$ & $21-30$ \\
\hline 5 & 21 and more & 0.05 & more than 300 & more than 8 & more than 30 \\
\hline
\end{tabular}

Scoring gives a comprehensive idea of the territorial distribution of constituent entities of the South of Russia according to the degree of development of the system of training scientific and pedagogical personnel for 2018 (Table 2):

Table 2. Assessment of the system for training highly qualified personnel in 2018 (compiled according to [8])

\begin{tabular}{|c|c|c|c|c|c|c|c|c|c|c|c|}
\hline \multirow[t]{2}{*}{$\begin{array}{l}\text { Subjects of the South of } \\
\text { Russia }\end{array}$} & \multicolumn{2}{|c|}{ 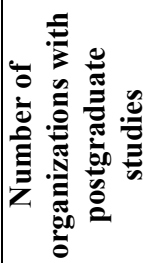 } & \multicolumn{2}{|c|}{ 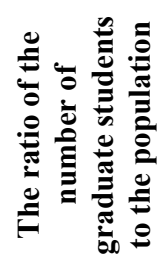 } & \multicolumn{2}{|c|}{ 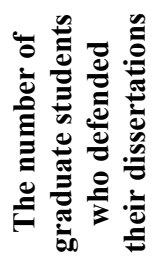 } & \multicolumn{2}{|c|}{ 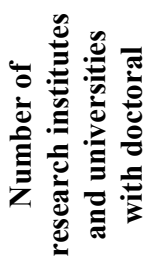 } & \multicolumn{2}{|c|}{ 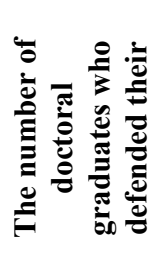 } & \multirow[t]{2}{*}{$\stackrel{\bar{\pi}}{\theta}$} \\
\hline & $\stackrel{\mathscr{E}}{\Xi}$ & 音 & $\partial^{e}$ & 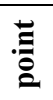 & 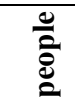 & $\stackrel{\Xi}{0}$ & $\stackrel{\mathscr{\Xi}}{\Xi}$ & $\vec{\Xi}$ & 䒕 & $\vec{\Xi}$ & \\
\hline Republic of Adygeya & 2 & 1 & 0.029 & 2 & 67 & 2 & 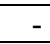 & - & 2 & 1 & 6 \\
\hline Republic of Kalmykiya & 2 & 1 & 0.064 & 5 & 11 & 1 & - & - & 3 & 1 & 8 \\
\hline Krasnodar region & 24 & 5 & 0.034 & 3 & 376 & 5 & 2 & 2 & 8 & 2 & 17 \\
\hline Astrakhan region & 6 & 2 & 0.040 & 4 & 67 & 2 & 1 & 1 & 7 & 2 & 11 \\
\hline Volgograd region & 12 & 3 & 0.032 & 3 & 394 & 5 & 4 & 3 & 14 & 3 & 17 \\
\hline Rostov region & 21 & 5 & 0.060 & 5 & 458 & 5 & 8 & 4 & 23 & 4 & 23 \\
\hline Republic of Crimea & 6 & 2 & 0.023 & 2 & 3 & 1 & - & - & 3 & 1 & 6 \\
\hline Sevastopol & 3 & 1 & 0.026 & 2 & 2 & 1 & - & - & 1 & 1 & 5 \\
\hline Republic of Dagestan & 14 & 3 & 0.02 & 2 & 117 & 3 & - & - & 1 & 1 & 9 \\
\hline Republic of Ingushetiya & 1 & 1 & 0.01 & 1 & 64 & 1 & - & - & - & - & 3 \\
\hline $\begin{array}{l}\text { Republic of Kabardino- } \\
\text { Balkaruya }\end{array}$ & 5 & 1 & 0.041 & 4 & 97 & 2 & 1 & 1 & 3 & 1 & 9 \\
\hline $\begin{array}{l}\text { Republic of Karachaevo- } \\
\text { Cherkessiya }\end{array}$ & 3 & 1 & 0.033 & 3 & 7 & 1 & - & - & - & - & 5 \\
\hline $\begin{array}{l}\text { Republic of North Osetiya } \\
\text { Alaniya }\end{array}$ & 7 & 2 & 0.05 & 5 & 74 & 2 & 2 & 2 & 3 & 1 & 12 \\
\hline Chechen Republic & 4 & 1 & 0.02 & 2 & 14 & 1 & - & - & 6 & 2 & 6 \\
\hline Stavropol region & 14 & 3 & 0.04 & 4 & 417 & 5 & 3 & 2 & 5 & 2 & 16 \\
\hline
\end{tabular}


Before carrying out zoning of the territory and analyzing the spatial differentiation of the constituent entities of the South of Russia in terms of the availability of scientific and pedagogical personnel of the highest qualification, it is necessary to get acquainted in more detail with the peculiarities and dynamics of indicators of graduate and doctoral studies over the past 5 years.

The directions of development of higher education and science in the south of the country generally correspond to all-Russian trends, but have their own regional characteristics, which are directly related to historical traditions, ethnic cultural features and rates of economic growth of the South and North Caucasian federal districts. Training of scientific, pedagogical and scientific personnel is carried out in the southern region both in state and non-state institutions of higher education (universities, academies, institutes) and research organizations. As of 2018, there are 124 organizations in the South of Russia that train future candidates and doctors of sciences (10\% of all scientific institutions in Russia), in which 9,965 people study.

\subsection{Post Graduate Studies}

Postgraduate training in the South of Russia is carried out in 125 institutions $(10.2 \%$ of the total number of organizations that train scientific and pedagogical personnel in the country), of which $61.2 \%$ of educational institutions are located in the Southern Federal District and only $38.4 \%$ in the North Caucasus Federal District.

The main centers for the preparation of graduate students in the Southern Federal District are traditionally Krasnodar region and Rostov region, quite strong scientific schools operate in the Republic of Crimea and Volgograd region. In the North Caucasus Federal District, only Stavropol region is comparable to them in scale. The socio-economic indicators of the North Caucasus Federal District have historically developed quite unevenly, which, in turn, influenced research activities in the region. The District is the smallest in the country in terms of the number of educational organizations that train scientific and pedagogical personnel, there is not a single flagship university, and the indicator of the number of working candidates and doctors of sciences is quite low. At the same time, Dagestan and Krasnodar region are leading among the southern regions in terms of the number of research institutes that train scientific and pedagogical personnel. The historically formed features of the territorial organization of higher educational institutions engaged in the training of graduate students, in connection with their significant hierarchical structure, determined the dominant role of large urban settlements, and first of all, administrative centers [14]. In this connection, the main concentration of educational services of higher education in the South of Russia is presented in the capitals of the regions: Rostov-on-Don, Krasnodar, Volgograd, as well as in large cities - Taganrog, Novocherkassk, Sochi, etc.

Among universities in the South of Russia, Southern Federal University is the leader in the preparation of graduate students. On the basis of SFedU, young scientists are trained in 26 areas of postgraduate studies; about 300 projects are being implemented with leading world universities. The SFedU is followed by the North Caucasian and Crimean federal universities. NCFU is a unique core of the scientific, educational and innovative sector of the economy of the North Caucasus region, in which the training of scientific and pedagogical personnel is carried out in 20 directions. KFU is still only building up its research potential, since it was formed in the shortest possible time for the socio-economic development of the region, where training is carried out in 22 areas of training. Following federal universities, an important role in the training of graduate students is played by three main multidisciplinary universities - Don State Technical University, Sochi State University and Volgograd State Technical University, which are considered one of the main 
suppliers of qualified personnel for the economy of the South of Russia, producing scientific and pedagogical personnel, knowledge and whose competencies meet the current needs of the largest industrial enterprises in the region.

Reforms and transformations of the education system in Russia have affected both the number of applicants and the number of institutions that train scientific and pedagogical personnel. In 2014, there were 96 higher educational institutions on the territory of the southern districts, by 2018 their number had decreased to 81 ; the number of research institutes implementing postgraduate programs decreased from 52 to 44 . This resulted in a decrease in the number of postgraduate students from 2011 to 2018 by $30 \%$. However, since 2016 there has been a positive dynamics of growth in the number of applicants for postgraduate studies in a number of southern regions: Kalmykia, North Ossetia, Chechnya, Volgograd region and Sevastopol. These changes are associated with an increase in the number of budget places in the Russian Federation as a whole in areas included in the list of priority areas for modernization and technological development of the Russian economy.

One of the most popular areas of training in postgraduate studies both in Russia and in the south of the country is 38.00 .00 Economics and Management (about $10 \%$ of graduate students), which is implemented by 50 higher educational institutions. Popular social and humanitarian areas of training: 44.00.00 Education and Pedagogical Sciences, 40.00.00 Law, 47.00.00 Philosophy, Ethics and Religious Studies, 45.00.00 Linguistics and Literature Studies. The latter is especially popular in the North Caucasus Federal District, due to the wide variety of living nationalities and the linguistic composition of the region. In the engineering and technical direction of training, the leading positions are taken by 09.06.00 Info science and computer technology, represented in 25 higher educational institutions. Training is conducted in such areas as 24.06.00 Aviation and rocket and space technology at the Southern Federal University and 14.00.00 Nuclear, thermal and renewable energy and related technologies at the Crimean Federal University and Sevastopol State University. Among the block of mathematical and natural sciences, the direction 06.00.00 Biological sciences is in demand, educational activities in which are carried out in 30 institutions of higher education. Agriculture is the most important branch of the economy, guaranteeing the country's sovereignty [14]. The South of Russia is a traditional leader in the agro-industrial complex, as a result of which, based on the demand of the economy for specialists, 8 state agricultural universities function, and the directions 35.06.01 Agriculture and 36.06.01 Veterinary and animal science are implemented in 6 more higher educational institutions.

The reduction in applicants naturally led to a decrease in the number of graduate students. Number of graduates in the period from 2013 to 2018 dropped significantly - by almost 2 thousand people (48.3\%). A particularly strong decline was noted in Adygea (57.3\%), Chechnya (54\%), Kalmykia (48.5\%), Stavropol region (48\%).

A key indicator of the activity in training highly qualified personnel is the number of graduates who successfully defended their dissertations. The share of graduates defended in the southern region is only one tenth of all defenses in the country and has a tendency to constant decline $(2014-13.4 \% ; 2018-10.5 \%)$. The total number of protections in the region also decreased significantly (by 76.7\%). In 2018, in total in the south of Russia, 231 people successfully defended mainly postgraduate students of the Southern Federal District (70.2\%). A low defense rate is observed in Crimea, Karachay-Cherkessia, North Ossetia and Chechnya, and in Kalmykia from 2015 to 2018 not a single successful defense took place. In terms of the effectiveness of postgraduate studies (the ratio of the number of defenses to the number of graduates), the most effective are Krasnodar and Stavropol regions, Volgograd region and Adygea. It is also worth noting Ingushetia, where, with the smallest number of graduate students in the south of the country (only 14 graduate students), in 2018 more than half of them went through a successful defense process and 
received the title of candidates of science. The lowest performance indicators were noted in North Ossetia, Dagestan and Chechnya.

\subsection{Doctoral Studies}

Doctoral studies as a form of training scientific and pedagogical personnel after 2013 is not the level of postgraduate education [15], but completely refers to the scientific field, the features and stages of preparing a dissertation for the degree of Doctor of Science are established by the Federal Law "On Science and State Scientific and Technical Policy" [9, $16]$.

In 2018, 22 institutions are implementing activities for the preparation of future doctors of science in the South of Russia. On average across the country, the southern region accounts for $8.5 \%$ to $10.5 \%$ of institutions that train doctoral students, of which more than $70 \%$ are located in the Southern Federal District. The leading positions in this indicator are occupied by the Rostov region ( 8 institutions that train scientific and pedagogical personnel of the highest category), the Volgograd region (4) and the Krasnodar region (3). There are 6 institutions on the territory of the North Caucasus Federal District, mainly concentrated in the Stavropol region. In 7 out of 15 regions of the South of Russia, doctors are not trained Adygea, Kalmykia, Sevastopol, Dagestan, Ingushetia, Karachay-Cherkessia, Chechnya.

According to the indicators of the dynamics of the preparation of doctoral students, there are similar trends as with postgraduate studies. 2010 to $201883.3 \%$ of research institutes and $40 \%$ of higher educational institutions have suspended their activities for the preparation of doctoral students. On average, the number of organizations providing training for future doctors of sciences has halved from 2014 to 2018. In the Southern Federal District, this process especially strongly affected the institutions of the Krasnodar region, their number decreased five times.

The leading universities for the preparation of doctoral students include the institutions of the Southern Federal District: Southern Federal University, Don State University, SouthRussian State Polytechnic University named after M.I. Platov, Don State Agrarian University, Rostov State Medical University (Rostov region); Volgograd State University, Volgograd State Technical University, Volgograd State Social and Pedagogical University (Volgograd region); State Kuban University and Kuban State Technological University (Krasnodar region). There are 6 institutions on the territory of the North Caucasian Federal University: North Caucasus Federal University, Stavropol State Agrarian University, North Ossetian State University named after K.L. Khetagurov and the North Caucasian Mining and Metallurgical Institute.

In 2018, 40 people were enrolled in doctoral studies in the southern districts. In the areas of training, the all-Russian tendency is repeated: economic areas, jurisprudence, informatics and computer technology, physics are leading. The peak of admission to doctoral studies coincides with the maximum admission to postgraduate studies. After 2010 , the number of students decreased by more than $70 \%$, in absolute terms the number of admission to doctoral studies decreased by 161 people, which, among other things, indicates low interregional academic mobility, as well as a rather weak interaction of Russian scientific schools with leading world research centers [17-18]. The main indicator of doctoral studies is the successful defense of a doctoral dissertation. The defense rate decreased 6 times from 2000 to 2017, and in 2018 only one doctoral dissertation was successfully defended.

\section{Results and discussion}


The state of the constituent entities of the South of Russia in terms of the level of provision of young scientists was determined based on the results of the point assessment of the system for training highly qualified personnel and was converted into points using the following scale: from 1 to 10 - a region of low income; from 10 to 20 - secured; from 20 or more - high-income. As a result, low-income, well-off and high-income regions of the South of Russia were identified in terms of the level of training of graduate students and doctoral students (Table 3).

Table 3. Differentiation of the subjects of the South of Russia by the availability of scientific and pedagogical personnel.

\begin{tabular}{|c|c|c|}
\hline Region of South of Russia & Amount of points & Condition \\
\hline Republic of Ingushetiya & 3 & low-income \\
\hline Sevastopol & 5 & low-income \\
\hline Republic of karachaevo-Cherkessiya & 5 & low-income \\
\hline Republic of Adygeya & 6 & low-income \\
\hline Republic of Crimea & 6 & low-income \\
\hline Chechen Republic & 6 & low-income \\
\hline Republic of Kalmykiya & 8 & low-income \\
\hline Republic of Dagestan & 9 & low-income \\
\hline Republic of Kabardino-Balkariya & 9 & low-income \\
\hline Astrakhan region & 11 & secured \\
\hline Republic of North Osetiya-Alaniya & 12 & secured \\
\hline Stavropol region & 16 & secured \\
\hline Krasnodar region & 17 & secured \\
\hline Volgograd region & 17 & secured \\
\hline Rostov region & 23 & \\
\hline
\end{tabular}

To illustrate the spatial differentiation of the regions of the South of Russia in terms of the availability of scientific and pedagogical personnel, the following map-scheme was drawn up: 


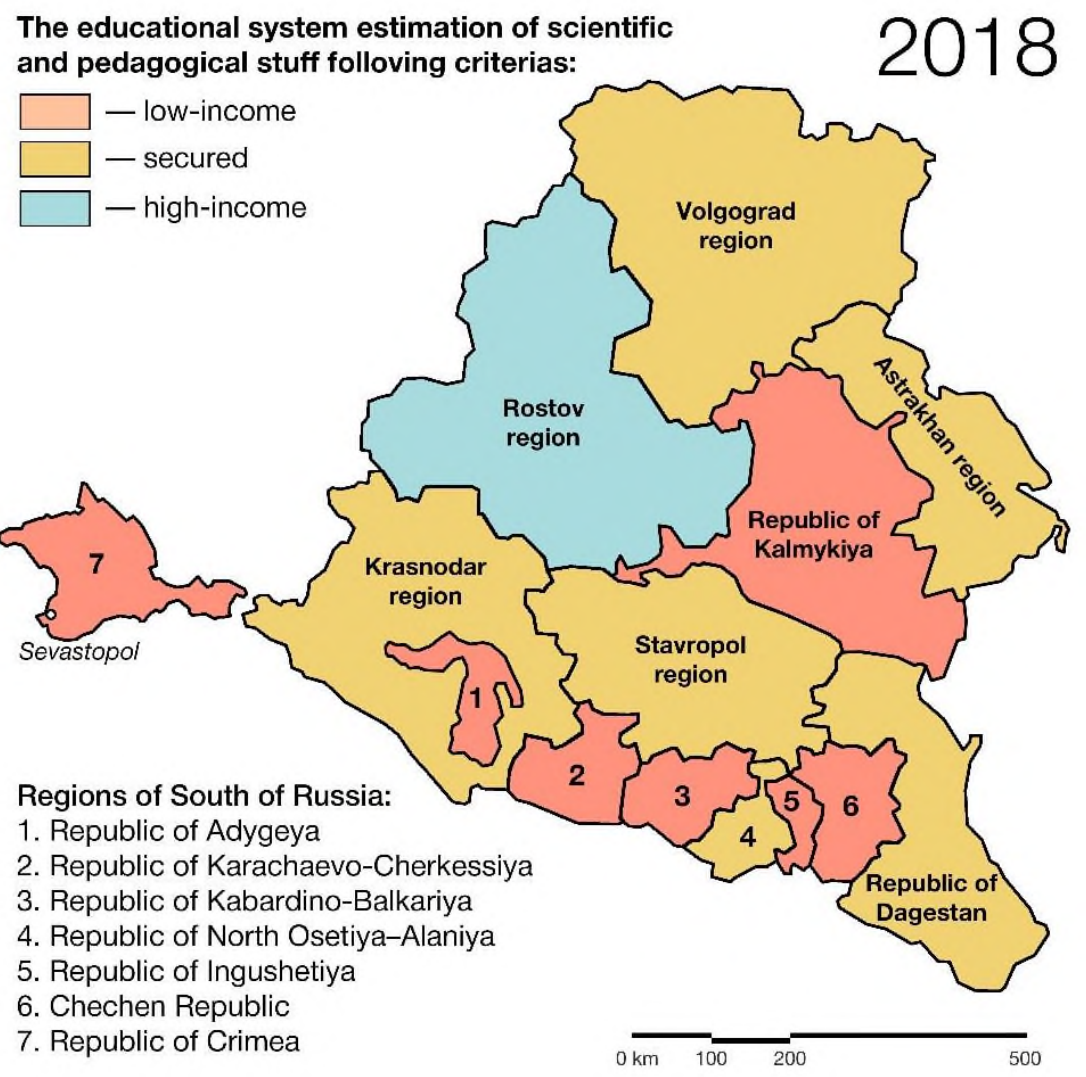

Fig. 1. Schematic map of the South of Russia on the provision of the education system for the training of highly qualified scientific and pedagogical personnel, 2018

The region in the South of Russia is the most highly provided with highly qualified personnel in Rostov region. It shows high indicators for most research criteria, with the exception of the number of research institutes and universities with doctoral studies and the number of doctoral graduates with a thesis defense, which is associated with a decrease in the indicators of doctoral studies from 2014 to 2018 (for example, in 2018, not a single doctoral student defended his defense within the established time frame).

A sufficient level of provision of the educational system with scientific and pedagogical personnel is characteristic of three regions - Krasnodar region, Volgograd region and Stavropol region. They have the highest performance indicators for postgraduate and doctoral studies, a high concentration of educational institutions, not only in administrative centers, but also in large cities (Sochi, Novorossiysk). The regions are also well off Astrakhan region and the Republic of North Osetia-Alania, but their average score is much lower.

The remaining nine regions should be classified as low-income in terms of the availability of highly qualified personnel. A particularly difficult situation is observed in five republics of the North Caucasus, with a difficult socio-economic situation - Ingushetia, Dagestan, Kabardino-Balkaria, Karachay-Cherkessia and Chechnya. These entities have a high potential for the development of such sectors of the economy as: agro-industrial complex, mechanical engineering, power engineering, tourism and recreation, which is reflected in the strategy of socio-economic development of the North Caucasus Federal 
District. In this connection, there is a demand for the formation of appropriate human resources for the needs of the economy. As part of the socio-economic development of these territories, it is planned to focus efforts on improving professional training and retraining programs in higher educational institutions and institutions of secondary vocational education, as well as to increase the availability of training and retraining for specialists in leading specialized Russian and foreign educational institutions (grants and system of educational loans), internships for graduates at leading specialized enterprises in various regions of the Russian Federation. Together, these efforts should have a positive impact on socio-economic development, improve the quality of life in the republics and bring the regions to a fundamentally new level of economic development.

With regard to the low values of Crimea and Sevastopol, it should be noted that this is the result of the ongoing modernization of the educational environment, and not an indicator of the quality of local education, since historically; higher educational institutions in Crimea were famous for their strong scientific school and educational traditions. In 2014, these regions only became part of Russia, and in 2016 they became part of the Southern Federal District. As a result, in a short time, significant changes and transformations were carried out in order to comply with the general criteria and regulatory legal acts of Russian education. Both subjects quickly switched to Russian educational standards. On the basis of the existing classical universities, the Crimean Federal and Sevastopol State Universities were created in a short time, the main goal of which is to create a scientific and educational base on the territory of Crimea and to contribute to the socio-economic development of the region. Currently, there is a process of improving the material base of universities, the construction of new laboratories and research centers, the opening of new educational areas.

\section{Conclusion}

The Russian educational system is an important part of the country's socio-economic life, one of the basic conditions for the development of all sectors of the economy. Reforming Russian higher education and science is associated with a number of key tasks, such as prioritizing fundamental scientific research with the intensive development of advanced practice-oriented industries, ensuring the integrity of the hierarchy of the educational system, maintaining the continuity of the traditions of Russian higher education and its active role in shaping the socio-cultural environment of the state $[19,20]$.

The training of highly qualified scientific and pedagogical personnel is the most important component of the formation of human resources in the south of the country, which determines the directions of development of the socio-economic sphere of society [7]. The main centers for the training of postgraduate and doctoral students in the South of Russia are located mainly in the Southern Federal District, in which the leading regions stand out: Rostov region and Krasnodar region. Southern Federal University, Don State Technical University, Kuban State Technological University, Volgograd State Technical University and Sochi State University are considered one of the main suppliers of qualified personnel for the economy of the South of Russia, releasing scientific and pedagogical personnel, the knowledge and competencies of which meet the current needs of the largest industrial enterprises of the region. Higher educational institutions of the Crimean Peninsula - the Crimean Federal University, the Crimean Engineering and Pedagogical University and the Sevastopol State University, after the reorganizations, are at the stage of disclosing and realizing their scientific potential. The leader in the training of scientific and pedagogical personnel and the most attractive investment region of the North Caucasus Federal District is the Stavropol region, where the leading higher educational institution of the district, the North Caucasus Federal University, is located. The educational policy of the 
North Caucasus Federal District is faced with the task of ensuring the growth and competitiveness of its higher educational institutions and research institutes in order to strengthen the scientific potential, since the lack of qualified personnel can aggravate the lagging behind the economy of the North Caucasus Federal District from the average Russian level.

According to the main indicators of the training of scientific and pedagogical personnel in the southern region, negative dynamics is observed, which is generally characteristic of the entire country. In most subjects, the number of higher educational institutions and research institutes implementing postgraduate and doctoral programs is decreasing, and, as a result, the number of incoming and outgoing graduate and doctoral students is decreasing. The decrease in the number of scientific and pedagogical personnel with the simultaneous reform of dissertation councils naturally negatively affects the effectiveness of training; the number of graduates who successfully defended their dissertations in the South of Russia has significantly decreased. However, in the past few years, there has been a positive dynamics of growth in the number of applicants to graduate school in a number of southern regions. These changes are associated with an increase in the country as a whole, budgetary places in areas are included in the list of priority areas for modernization and technological development of the Russian economy.

Currently, the educational models of postgraduate and doctoral studies are undergoing significant changes, which are aimed at the Europeanization of education. It is important that in this difficult time such paths of development of the education system are chosen that could find the necessary balance between the traditions developed over centuries, the approaches of fundamental Russian science and modern innovative directions that can give impetus to the development of new scientific knowledge and breakthrough technologies. The process of reforming the system of training young scientists should be carried out in such a way that in the future it does not lead to an acute shortage of scientific and pedagogical personnel both in the region and in the country, since the development of science, technology, the introduction of innovations in all spheres of activity is provided by highly qualified personnel with fundamental knowledge, creative thinking, the ability to find extraordinary solutions and dedication.

\section{References}

1. O. Fedotova, Russian Education in the System of Global Interactions: Trends and Theoretical Projection, Procedia - Social and Behavioral Sciences, 214, 414-421 (2015)

2. Z. Mingaleva, I. Mirskikh, Globalization in Education in Russia, Procedia - Social and Behavioral Sciences, 47, 1702-1706 (2012)

3. A. Kozachek, The Bologna Professional Training Degrees in Europe and Russia: Analysis and Systematization, Procedia - Social and Behavioral Sciences, 214, 235$242(2015)$

4. F. Fatkullina, E. Morozkina, A. Suleimanova, Modern Higher Education: Problems and Perspectives, Procedia - Social and Behavioral Sciences, 214, 571-577 (2015)

5. A. Vorontsov, E. Vorontsova, Current Trends in Russian Scientific and Educational Development in the Context of Worldwide Globalization, Procedia - Social and Behavioral Sciences, 214, 1156-1164 (2015) 
6. Y. Glebova, N. Yasnitskaya, The Evaluation of the Innovative Activity of Modern Russia's Higher Educational Establishments and Ways of its Fostering, Procedia Social and Behavioral Sciences, 191, 2374-2381 (2015)

7. D. Pavlenko, L. Barykin, S. Nemeshaev, E. Bezverhny, Individual approach to knowledge control in learning management system, Procedia Computer Science, 169, 259-263 (2020)

8. Russian statistical yearbook. 2014-2018: Statistical collection (Rosstat, Moscow, 2018)

9. Federal Law of December 29, 2012 N 273-FZ (as amended on December 27, 2019) "On Education in the Russian Federation" (as amended and supplemented, entered into force on 01/08/2020) The official Internet portal of legal information URL: http://www.pravo.gov.ru (Last accessed 08/28/2020)

10. A. V. Rezaev, Bologna Process: On the way to a Common European Higher Education Area, International Encyclopedia of Education (Third Edition), $772-778$ (2010)

11. S. Nielsen, Vocational Education and Training Teacher Training, International Encyclopedia of Education (Third Edition), 503-512 (2010)

12. Regions of Russia. Socio-economic indicators - 2018. URL: https://rosstat.gov.ru/folder/210/document/47652 (Last accessed 08/28/2020)

13. Education in numbers - 2017 .URL: https://www.hse.ru/primarydata/oc2017 (Last accessed 08/28/2020)

14. Y. Merinova, Y. Merinov, Features of the spatial change in the educational landscape and reforming the vocational education system in the Southern Federal District. International Journal of Economics and Education, 1, 91-100 (2017)

15. O. Fedotova, V. Latun, Y. Merinova, A. Ertel, The evolution of the institutional structure of the agricultural education in Russia E3S Web of Conferences, 175, 15026 (2020)

16. Official website of the Ministry of Science and Higher Education of the Russian Federation https://minobrnauki.gov.ru/ (Last accessed 08/28/2020)

17. I. B. Ardashkin, N. V. Martyushev, T. V. Sidorenko, Methodology of enhancement of linguistic competences of research and educational higher school personnel, Procedia - Social and Behavioral Sciences, 166, 254 - 258 (2015)

18. P. J. Mitchell, L. A. Mitchell, Implementation of the Bologna Process and Language Education in Russia, Procedia - Social and Behavioral Sciences, 154, 170-174 (2014)

19. M. S. Mioara, The Impact of Technological and Communication Innovation in the Knowledge-Based Society, Procedia - Social and Behavioral Sciences, 51, 263-267 (2017)

20. O. Aydarova, Universal principles transform national priorities: Bologna Process and Russian teacher education, Teaching and Teacher Education, 37, 64-75 (2014) 